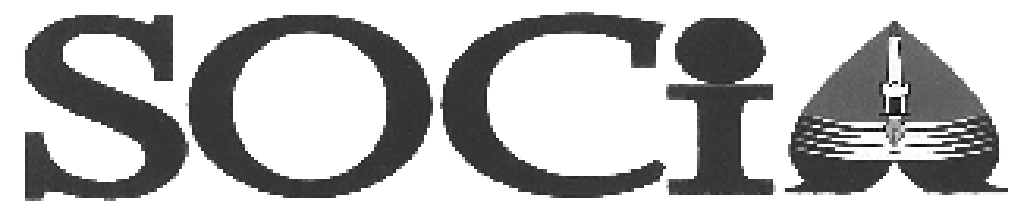

\title{
PEMAHAMAN GURU IPS TERHADAP PENDEKATAN SAINTIFIK DAN PENILAIAN AUTENTIK DALAM KURIKULUM 2013
}

\author{
M Samsulhadi dan Ishartiwi \\ Program Studi Ilmu Pengetahuan Sosial, Program Pascasarjana UNY \\ samsul.hadi176@yahoo.co.id
}

\begin{abstract}
Abstrak
Penelitian ini bertujuan untuk mengungkapkan pemahaman guru IPS terhadap pendekatan saintifik dan penilaian autentik dalam Kurikulum 2013 yang meliputi: 1) pemahaman guru terhadap pendekatan saintifik yang terdiri atas: (a) konsep pembelajaran dengan pendekatan saintifik, (b) tujuan pembelajaran pendekatan saintifik, (c) prinsip pendekatan saintifik, dan (d) langkah-langkah pembelajaran dengan pendekatan saintifik. 2) pemahaman guru terhadap penilaian autentik yang terdiri atas: (a) konsep penilaian autentik, (b) penilaian autentik dalam istrumen penilaian kompetensi sikap, (c) penilaian autentik dalam istrumen penilaian kompetensi pengetahuan dan, (d) penilaian autentik dalam istrumen penilaian kompetensi keterampilan.Jenis penelitian ini adalah penelitian kuantitatif dan kualitatif. Penelitian ini dilakukan di SMP Negeri se Kecamatan Praya Timur dengan subyek penelitiannya semua guru mata pelajaran IPS berjumlah 18 orang guru. Teknik pengumpulan data yang digunakan adalah, angket, wawancara observasi. Wawancara digunakan untuk mengetahui pemahaman terhadap pembelajaran dengan pendekatan saintifik dan penilaian autentik. Sedangkan observasi digunakan untuk melihat pelaksanaan pendekatan saintifik dan penilaian autentik. Hasil penelitian menunjukkan bahwa: (1) pemahaman guru mata pelajaran IPS terhadap pendekatan saintifik pada kategori sangat sesuai sebanyak 3 guru, kategori sesuai sebanyak 11 guru, kategori tidak sesuai sebanyak 4 guru. Menunjukkan pemahaman guru terhadap pendekatan saintifik sebagian besar dipahami oleh guru. (2) pemahaman guru mata IPS terhadap penilaian autentik pada kategori sangat sesuai sebanyak 2 guru, kategori sesuai sebanyak 7 guru, kategori tidak sesui sebanyak 9 guru.
\end{abstract}

Kata kunci: Pemahaman, Kurikulum 2013, Pendekatan Saintifik. Penilaian Autentik

Abstrak

This research was aimed at revealing the teachers' comprehension of Social Science about scientific approach and authentic assessment on curriculum 2013 that consist of: (1) teachers' comprehension of scientific approach that comprises; (a) teaching concept using the scientific approach, (b) the aims of the teaching using the scientific approach, (c) the principles of scientific approach, and (d) teaching procedures of using scientific approach. (2) Teachers' comprehension of scientific assessment that comprises; (a) the concepts of authentic assessment, (b) the authentic assessment in instrument of affective competency, (c) the authentic assessment in instrument of knowledge competency, and (d) the authentic assessment in instrument of skills competency. The kind of this research used quantitative and qualitative research. The object of this research conducted in all Junior High Schools of East Praya Subdistrict, Central Lombok Regency in which the subjects were 18 teachers. The techniques of collecting data used questionnaire, interview, and observation. The interview and questionnaire were used to know the teachers' comprehension of the teaching using scientific approach and authentic assessment, whereas the observation was used to know the application of the teaching using scientific approach and authentic assessment. The result of this research showed that: (1) the category of teachers' comprehension of Social Science Subject of scientific approach was in very proportional in which there are 3 teachers, 11 teachers in proportional category, 4 teachers in not proportional category. So, the teachers' comprehension of scientific approach was mostly understood by the teachers; (2) the category of teachers' comprehension of Social Science Subject about authentic assessment was in very proportional in which there are 2 teachers, 7 teachers in proportional category, 9 teachers in not proportional category. So, the teachers' comprehension of assessment authentic in curriculum 2013 was mostly understood by the teachers.

Key words : Comprehension, Curriculum 2013, Scientific Approach and Authentic 


\section{PENDAHULUAN}

Kurikulum 2013 melanjutkan Pengembangan Kurikulum Berbasis Kompetensi yang telah dirintis pada tahun 2004 dengan mencakup kompetensi sikap, pengetahuan, dan keterampilan secara terpadu. Pengembangan Kurikulum 2013 merupakan bagian dari strategi meningkatkan capaian pendidikan, disamping kurikulum terdapat sejumlah faktor diantaranya: lama siswa bersekolah, lama siswa tinggal di sekolah, pembelajaran siswa aktif berbasis kompetensi, buku pegangan atau buku babon, dan peranan guru sebagai ujung tombak pelaksana pendidikan (Hidayat, 2013, p113).

Elemen perubahan yang menjadi ciri Kurikulum 2013 adalah menyangkut empat standar pendidikan yakni standar kompetensi lulusan (SKL), standar proses, standar isi, dan standar penilaian. Dalam standar proses yang semula terfokus pada eksplorasi, elaborasi, dan konfirmasi dilengkapi dengan mengamati, menanya, mengolah, menalar, menyajikan, menyimpulkan dan mencipta (scientific approach), Ilmu Pengetahuan Alam (IPA) dan Ilmu Pengetahuan Sosial (IPS) masing-masing dibelajarkan secara terpadu. Sedangkan dalam proses penilaian menuju penilaian autentik (mengukur semua kompetensi sikap, keterampilan, dan pengetahuan) (Hidayat, 2013, pp 128-129).

Ilmu Pengetahauan Sosial (IPS) di belajarkan secara terpadu artinya bahwa: (1) adanya keterkaitan antara berbagai aspek dan materi yang tertuang dalam Kompetensi Dasar Ilmu Pengetahauan Sosial; (2) pembelajaran terpadu juga dapat dikatakan pembelajaran yang memadukan materi beberapa pembelajaran yang memadukan materi beberapa pembelajaran dan kajian ilmu dengan satu tema; (3) keterpaduan dalam pembelajaran Ilmu Pengetahauan Sosial dimaksudkan agar pembelajaran Ilmu Pengetahuan Sosial lebih bermakana, efektif, dan efesien. Ilmu Pengetahauan Sosial (IPS) menekanakan pada pengetahuan tentang bangsanya, semangat kebangsaan, patriotisme, serta aktivitas masyarakat di bidang ekonomi dalam ruang atau space wilayah Negara Kesa- tuan Republik Indonesia (NKRI) dilembagakan sebagai mata pelajaran integrative social stadien, bukan sebagai pendekatan disiplin ilmu (Kemendikbud, 2013, p127).

Perkembangan pendidikan yang ditandai dengan perubahan kurikulum yang terjadi dalam rentang waktu segitar 10 tahun akhir akhir ini ( mulai dari kurikulum 1975 - 2013) memang telah membawa perubahan kurikulum dalam aspek konseptual namun secara factual hal ini belum terelihat secara signifikan. Para guru sebagai ujung tombak pendidikan banyak yang belum memahami konsep kurikulum yang sedang berkembang sehingga kurikulum berubah tapi cara pembelajaran guru termasuk dalam aspek penilaian tidak berubah alias jalan ditempat (Febri Hendri. Kritik Kurikulum 2013: Layu Sebelum Berkembang. Kompas, Jumat, 19 September 2014.)

Kemendikbud melalui pemerintah kabupaten/kota memang telah melatih ribuan guru. Tetapi, tidak ada jaminan bahwa guru mudah memahami semangat perubahan kurikulum tersebut. Sebenarnya implementasi kurikulum 2013 sangat membutuhkan dukungan penuh dan kreativitas para guru. Sayangnya, belum semua guru paham maksud dari kurikulum itu. Sebab, pelatihan tidak berjalan sempurna sebagaimana yang dibayangkan (Kompas http:// www.aswanblog.com/2013/04/problematika-kurikulum-2013tinjauan.html)

Berdasarkan observasi dan wawancara di lapangan dengan guru mata Pelajaran Ilmu Pengetahuan Sosial (IPS) di Sekolah Menengah Pertama Negeri (SMPN) se Kecamatan Praya Timur Kabupaten Lombok Tengah beranggapan bahwa kurikulum 2013 sulit diterapkan bila tidak memahaminya, karena pelaksanaan pelatihan terhadap guru belum cukup untuk memberikan pemahaman mengenai kurikulum yang diterapkan. Dengan demikian, para guru menganggap bahwa kurikulum ini sulit diterapkan dengan pemahaman yang minim. Akibatnya guru kebingungan.

Penerapan Kurikulum 2013 untuk sekolah Menegah Pertama Negeri di Kecamatan Praya Timur, mengalami kendala karena sebagian guru mata pelajaran Ilmu Pengetahuan 
Sosial, belum menpunyai buku Kurikulum 2013, sehingga guru sebagai pembimbing dalam sebuah pembelajaran tidak mempunyai pegangan untuk menerapkan mata pelajaran yang sesuai dengan kurikulum yang berlaku.

Guru mata pelajaran Ilmu Pengetahuan Sosial (IPS) Sekolah menegah Pertama Negeri (SMPN) di Kecamatan Praya Timur mengalami permasalahan dalam melaksan kurikulum 2013, karena pengetahuan dan pemahaman guru masih kurang baik terhadap pembebelajaran Ilmu Pengetahuan Sosial yang di ajarakan secar terpadu, juga menujukkan pemahaman guru masih bervariasi terhadap pendekatan scientific approach dan penilaian autentik karena guru-guru tidak memiliki dokumen kurikulum yang lengkap dan memadai, serta guru Ilmu Pengetahuan Sosial belum mendapatkan pelatihan-pelatihan yang intensif.

Guru menggunakan scientific approach dan penilaian autentik dalam pembelajaran Ilmu Pengetahuan Sosial (IPS). Guru belum mampu menggunakan pendekatan seperti mengamati, menanya, mengolah, menalar, menyajikan, menyimpulkan dan menciptakan, karena mata pelajaran Ilmu Pengetahuan Sosial di ajarkan secara terpadu. Pendekatan saintifik adalah pembelajaran yang terdiri atas kegiatan mengamati (untuk mengidentifikasi masalah yang ingin diketahui), merumuskan pertanyaan (merumuskan hipotesis), mengumpulkan data/informasi dengan berbagai teknik, mengolah/menganalisis data dan informasi, menarik kesimpulan dan mengomunikasikan hasil kesimpulan atau mungkin temuan lain dil lauar rumusan masalah untuk memperoleh pengetahuan, keterampilan dan sikap (Kemendikbud, 2013, p3).

Penilaian hasil siswa guru menggunakan penilaian autentik. Ada beberapa aspek yang dinilai pada saat pembelajaran berlangsung yakni penilaian sikap, keterampilan, pengetahuan dan skill. Sehingga membuat guru di Sekolah Menegah Pertama Negeri (SMPN) se Kecamatan Praya Timur kewalahan, karena pada saat itu juga guru harus membimbing siswa dalam pembelajaran. Penilaian autentik merupakan penilaian yang dilakukan secara komprehensif untuk menilai mulai dari masukan (input), proses,dan keluaran (output) pembelajaran (Salinan, Lampiran nomor 66, Kemendikbud, 2013, p2).

Pelaksanaannya pendekatan saintifik dan penilaian autentik dalam Kurikulum 2013 tidak bisa ditawar-tawar lagi, maka setiap guru dituntut untuk melek kurikulum. Memiliki sikap untuk merespon lebih awal terkait dengan perubahan kurikulum, memahami tujuan, mengetahui elemen perubahan, serta isu-isu terkait rancangan struktur kurikulum dapat memberikan bekal awal bagi guru dalam menyongsong penerapan kurikulum 2013. Pengembangan pemahaman guru terhadap kurikulum baru, harus pula didukung secara penuh oleh pemerintah. Memfasilitasi para guru dalam pelatihan yang tepat dan bermakna, sudah menjadi kewajiban pemerintah

Penting diingat, apapun kurikulum yang akan diberlakukan, guru memiliki peran vital dalam penjabaran kurikulum tersebut di sekolah. Guru adalah ujung tombaknya. Jika guru tidak memahami konsep kurikulum baru ini dengan baik, tujuan pendidikan akan sulit dicapai. Tentu saja, optimalisasi peran guru harus menjadi titik tekannya. Karena pada praktiknya, guru lah yang akan menerjemahkan kurikulum ini secara langsung di ruang-ruang pembelajaran. Acapkali terjadi, kurikulum yang unggul menjadi mandul karena pemahaman dan penguasaan guru terhadap kurikulum yang tumpul.

Seperti yang telah dijelaskan di atas, maka perlu dielitit mengenai "Pemahaman guru mata pelajaran Ilmu Pengetahuan Sosial (IPS) terhadapa pendekatan saintifik dan penilaian autentik dalam Kurikulum 2013", sehingga dapat menjadi tolak ukur dalam pelaksanaan Kurikulum 2013 di Sekolah Menengah Pertama Negeri (SMPN) se Kecamatan Praya Timur.

\section{METODE}

Penelitian ini menggunakan pendekatan campuran (kuantitatif dan kualitatif). Alasan menggunakan pendekatan campuran yakni untuk mengumpulkan informasi tentang pendekatan saintifik dan penilaian autnetik. In- 
formasi tersebut sebagai dasar atau landasan untuk memaparkan semua fenomena dan kejadian yang terjadi dalam penelitian serta membuat keputusan tentang program yang telah dilaksanakan. Penelitian ini dilakukan di SMP Negeri se Kecamatan Praya Timur Kabupaten Lombok Tengah. Waktu penelitian ini dilaksanakan kurang lebih 4 bulan yaitu bulan November 2014 sampai dengan Februari 2015. Sampel dalam penelitian ini adalah semua guru Ilmu Pengetahuan Sosial yang berjumlah 18 orang guru 3 . Informan ditentukan atas pertimbangan tujuan penelitian dengan kriteria jaringan informan atau informan yang sesuai dengan yang peneliti butuhkan.

Instrumen dalam penelitian ini adalah peneliti itu sendiri (human instrument) yang berfungsi memilih informan sebagai sumber data, melakukan pengumpulan data, menilai kualitas data, analisis data, menafsirkan data dan membuat kesimpulan atas temuannya.

Teknik pengumpulan data dalam penelitian ini adalah penyebaran angket, observasi, wawancara dan dokumentasi. Angket digunakan untuk mengungkap pemahaman terhadap guru terhadap pendekatan saintifik dan penilaian autentik dalam Kurikulum 2013. Wawancara digunakan untuk mendapatkan data tentang pendekatan saintifik dan penilaian autentik dalam Kurikulum. Pengumpulan data dengan wawancara ditujukan pada informan terpilih yang pertimbangannya adalah relevansi dengan tujuan penelitian. Wawancara dilakukan untuk melengkapi data angket dan observasi sebagai bentuk triangulasi data.

Analisis data yang digunakan dalam penelitian adalah analisis data deskriptif kuantitatif dan kualitatif. Data yang diperoleh dengan teknik kuisioner dianalisis dengan teknik analisis deskriptif kuantitatif. Data dikumpulkan dan dianalisis untuk dideskripsikan berdasarkan sebaran data yang digunakan dalam penelitian ini adalah skor minimum, skor maksimum, rerata (mean), median, modus, simpangan baku, dan persentase. Data disajikan dalam bentuk tabel dan histogram serta analisis deskriptif ini digunakan untuk memaparkan karakteristik data hasil penelitian dan menjawab permasala- han deskriptif. Analisis data dilakukan dengan tahapan: (1)penskoran jawaban responden; (2) penjumlahan skor total masing-masing komponen; (3)pengelompokan skor yang didapat; (4)mengolah skor yang didapat oleh responden berdasarkan keterkaitan antar variabel.

Sebelum dianalisis, dilakukan proses kuantifikasi data dari kuisioner, setelah dilakukan kuantifikasi selanjutnya data tersebut dianalisis dengan menggunakan statistik deskriptif melalui bantuan komputer program SPSS for Windows 17 untuk mendapatkan: mean, median, simpangan baku, skor minimum, dan skor maksimum. Instrumen berbentuk skala likert yang menggunakan empat alternatif jawaban, sehingga skor maksimum ideal diperoleh apabila semua butir pada komponen tersebut mendapat skor maksimum pada alternatif jawaban dan skor minimum ideal diperoleh apabila semua butir pada komponen tersebut mendapat skor 1 atau skor minimum pada alternatif jawaban. Keseluruhan skor yang diperoleh disubstitusikan ke dalam tingkat kecenderungan yang dipakai sebagai kriteria dalam evaluasi.

Tingkat kecenderungan dibagi empat kategori dengan jarak 1 SD (ideal). Berkaitan dengan distribusi normal peneliti mengadopsi dari pendapat Mardapi (2008,p 123) yang mengelompokan ke dalam kategori sebagaimana pada tabel di bawah ini:

Tabel 1. Kriteria Pemahaman

\begin{tabular}{rll}
\hline \multicolumn{1}{c}{ Skor } & & \multicolumn{1}{c}{ Kategori } \\
\hline $\mathrm{X} \geq \overline{\mathrm{X}}+1 . \mathrm{SBx}$ & $:$ & Sangat Sesuai \\
$\overline{\mathrm{X}}+1 . \mathrm{SBx}>\mathrm{X} \geq \overline{\mathrm{X}}$ & $:$ & Sesuai \\
$\overline{\mathrm{X}}>\mathrm{X} \geq \overline{\mathrm{X}}-1 . \mathrm{SBx}$ & $:$ & Tidak Sesuai \\
$\mathrm{X}<\overline{\mathrm{X}}-1 . \mathrm{SBx}$ & $:$ & Sangat Tidak \\
& & Sesuai
\end{tabular}

Berdasarkan kriteria di atas disusun standar skor kategori kecenderungan variabel dan indikator variabel penelitian yaitu dengan kategori sangat sesuai, sesuai, tidak sesuai, dan sangat tidak sesuai $r$. Untuk mengetahui tingkat kecenderungan skor dari rata-rata masingmasing sub variabel, dilakukan dengan mencari mean rata-rata ideal ( ) dan simpangan baku. 
Keterangan:

$\mathrm{X}=$ Skor akhir rata-rata

$\overline{\mathrm{X}}=$ Rerata skor keseluruhan

$\mathrm{SBx}=$ Simpangan baku

Data yang bersifat kualitatif yang diperoleh dari hasil wawancara dianalisis dengan analisis kualitatif. Teknik analisis kualitatif yang digunakan adalah model interaktif Miles \& Huberman. Aktivitas dalam analisis data, yaitu data reduction, data display, dan conclusion drawing/verification (Sugiyono, 2010, pp 337345).

Setelah menganalisis data kemudian dilanjutkan dengan keabsahan data kualitatif yaitu dengan cara triangulasi. Triangulasi dalam penelitian ini adalah dengan membandingkan informasi dari informan yang satu dengan informan yang lain, misalnya dari guru IPS yang satu dengan guru IPS yang lain sehingga informasi yang didapat diperoleh kebenarannya. Proses ini berlangsung secara terus menerus selama penelitian berlangsung.

\section{HASIL DAN PEMBAHASAN}

Deskripsi data hasil penelitian ini disajikan dari masing-masing variabel terkait objek penelitian pemahaman guru IPS terhadap pendekatan saintifik dan penilaian autentik di SMP Negeri se Kecamatan Praya Timur Kabupaten Lombok Tengah. Deskripsi data yang disajikan meliputi rata-rata (mean), median, modus, standar deviasi, skor minimum, skor maksimum, dan distribusi frekuensi. Hasil perhitungan skor tersebut diperoleh dengan pengolahan data statistik berdasarkan program SPSS versi 17,0. Hal ini dapat dilihat pada tabel tabel statistik di bawah ini.

Tabel 2. Kategori Kecenderungan Pemahaman Guru Dalam Pendekatan Saintifik

\begin{tabular}{|c|c|c|c|}
\hline No & Skor Guru & $\mathbf{F}$ & $\mathbf{K}$ \\
\hline 1 & $X \geq 45,5$ & 3 & $S S$ \\
\hline 2 & 45,5 ? $X \geq 35$ & 11 & $S$ \\
\hline 3 & 35 回 $X \geq 24,5$ & 4 & $T S$ \\
\hline 4 & $X<24,5$ & 0 & STS \\
\hline \multicolumn{2}{|r|}{ Jumlah } & 18 & \\
\hline
\end{tabular}

Berdasarkan tabel 2, dapat diketahui pemahaman guru dalam pendekatan saintifik pada kategori sangat sesuai sebanyak 3 guru kategori sesuai sebanyak 11 guru, kategori tidak sesuai 4 guru, dan kategori sangat tidak sesuai sebanyak 0 guru. Hal ini menunjukkan bahwa pemahaman guru IPS terhadap pendekatan saintifik dalam Kurikulum 2013 di SMP Negeri se Kecamatan Praya Timur Kabupaten Lombok Tengah yang meliputi indikator pemahaman konsep pendekatan saintifik, tujuan pendekatan saintifik, prinsip penekatan saintifik, dan langkah-langkah pendekatan saintifik dalam kategori sangat sesuai yang ditunjukkan oleh persentase terbesar perolehan skor tersebut, hal tersebut menunjukan kondisi sebagian besar guru memahami pendektan saintifik dalam Kurikulum 2013.

Tabel 3. Kategori Kecenderungan Pemahaman Guru Terhadap Penilaian Autentik

\begin{tabular}{|c|c|c|c|}
\hline No & Skor Guru & $\mathbf{F}$ & $\mathbf{K}$ \\
\hline 1 & $X \geq 81,25$ & 2 & SS \\
\hline 2 & 81,25 ? $X \geq 6,25$ & 7 & $S$ \\
\hline 3 & 62,5 ? $X \geq 43,5$ & 9 & $T S$ \\
\hline 4 & $X<43,75$ & 0 & STS \\
\hline \multicolumn{2}{|c|}{ Jumlah } & 18 & \\
\hline
\end{tabular}

Berdasarkan tabel 3, dapat diketahui pemahaman guru terhadap penilaian autentik pada kategori sangat sesuai sebanyak 2 guru kategori sesuai sebanyak 7 guru, kategori tidak sesuai 9 guru, dan kategori sangat tidak sesuai sebanyak 0 guru. Hal ini menunjukkan bahwa pemahaman guru IPS terhadap penilaian autentik dalam Kurikulum 2013 di SMP Negeri se Kecamatan Praya Timur Kabupaten Lombok Tengah yang meliputi indikator pemahaman konsep penilaian autentik, penilaian kompetensi sikap, penilaian kompetensi pengetahuan, dan penilaian kompetensi keterampilan dalam kategori sangat tidak sesuai ditunjukkan oleh persentase terbesar perolehan skor tersebut, hal tersebut menunjukan kondisi sebagian besar guru belum memahami penilaian autentik dalam Kurikulum 2013 secara komprehensif.

Hasil penelitian dari data kuantitatif 
tersebut diperkuat oleh data kualitatif. Hasil data kualitatif dengan wawancara 4 guru IPS SMP Negeri se Kecamatan Praya Timur yang memeberikan pernyataan sangat sesuai dengan pendekatan saintifik, dua guru yang menjawab pernyataan sangat sesuai dalam pendektan saintifik dalam Kurikulum 2013, terkait pemahaman konsep, tujuan, prinsip, dan langkah-langkah dalam pendekatan saintifik juga tanggapan dan pemahaman guru terhadap keberlanjutan Kurikulum untuk diterapkan sehingga dalam pelaksanaannya dapat berjalan secara sistematis dan maksimal, menyatakan bahwa pemahaman guru tentang konsep pembelajaran dengan pendekatan saintifik yaitu suatu pendekatan dalam pembelajaran yang dapat mengembangkan daya kritis siswa, penalaran siswa, siswa lebih kreatif, siswa lebih aktif bukan pasif dalam mengemukakan pendapatnya dan idenya. Scientific Method, Observation, Question, Hypothesis, Experiment, dan Evaluation (Christine V. M, 2014, pp 2-3).

Selanjutnya, berkaitan dengan hal di atas menyatakan bahwa "... specifically, innovators engage the following behavioral skills more frequently: questioning, observing, networking, experimenting" (Jeff Dyer, dkk, 2011, p 23). Selain itu, Apabila seorang guru telah melaksanakan pembelajaran sesuai dengan tujuan pembelajaran dengan pendektan saintifik tentu akan dapat meningkatkan kemampuan siswa dalam pembelajaran Ilmu Pengetahuan Sosial dan memang tujuan seperti ini sangat di perlukan dalam pembelajaran di kelas. lebih lanjut mengenai prinsip pembelajaran dengan pendekatan saintifik.

Dalam prinsip pendekatan saintifik menyarankan pembelajarannya yang lebih aktif siswa guru hanya membimbing prinsip ini memberikan ruang yang luas untuk siswa lebih aktif dalam proses pembelajaran di kelas terutama pada pembelajaran IPS. Wiyanto Sopyan, Nugroho, \& Wibowo (2006). Model pembelajaran sains berbasis empat pilar pendidikan, yaitu suatu model pembelajaran yang diharapkan dapat memfasilitasi siswa untuk belajar mengetahui jawaban dari suatu masalah yang berupa produk sains (learning to know) melalui proses bekerja ilmiah (learning to do) yang dilakukan secara kolaboratif (learning to live together), sehingga diharapkan siswa menjadi terbiasa berpikir dan bertindak ilmiah seperti yang biasa dilakukan oleh ilmuwan. Dengan adanya pemberlakuan kurikulum 2013 maka diupayakan untuk menggunakan adanya langkah-langkah pendekatan saintifik walaupun banyak kendala-kendala. Salah satu kendalanya yaitu dalam hal melaksanakan langkah-langkahnya secara sistematis, terkadang langkah-langkah dalam pendekatan saintifik tersebut tidak sistematis dalam penerapannya. Menyatakan sebagai pelaksana kurikulum di sekolah siap untuk menerapkan kurikulum baru terutama dalam pembelajaran dengan scientific approach pada mata pelajaran Ilmu Pengetahauan Sosial. Namun, mengingat waktu yang mendesak dalam implementasi kurikulum 2013 maka diharapkan pemerintah melakukan sosialisasi dan pelatihan guru dan menyentuh semua lapisan guru karena guru harus memiliki pemahaman tentang kurikulum dan memahami proses dimana kurikulum dapat dikembangkan sehingga selain bertugas untuk melaksanaan kurikulum guru juga harus bertanggung jawab untuk mengembangkan kurikulum seperti pembelajaran dengan pendektan saintifik.

Selanjutnya berdasarkan hasil wawancara dengan dua guru IPS yang dalam kategori tidak sesuai pemahamannya terhadap pendekatan saintifik di antaranya: memahami konsep, tujuan, prinsip, dan langkah-langkah dalam pendekatan saintifik dalam Kurikulum 2013, juga tanggapan dan pemahaman guru terhadap keberlanjutan Kurikulum 2013 untuk di hentikan atau dilanjutkan, menyatakan bahwa pemahaman guru tentang konsep pembelajaran dengan pendekatan saintifik yaitu: Terkait kurikulum 2013 yang sekarang digunakan. Dari adanya pendekatan saintifik ini dapat mengaktifkan siswa di kelas dan membuat siswa lebih inovatif serta kreatif untuk menemukan masalah-masalah yang berhubungan dengan tema yang akan dibahas.

Pembelajaran dengan pendekatan scientific approach merupakan pembelajaran yang diawali dengan kegiatan mengamati, menanya, 
mengumpulkan data, mengasosiasi dan mengomunikasikan agar peserta didik menjadi akatif dalam proses pembelajaraa. Dalam prose situ bantuan guru sangat diperlukan. Oleh karena itu guru harus memahami pembelajaran saintifik agara mampu melaksanakanya dengan optimal. Kurikulum 2013 yang menekankan pembelajaran saintifik adalah kurikulum baru, saya yakin bertujuan sangat bagus akan tetapi saya belum bisa memberikan pendapat karena saya hanya melihat sepintas buku Kurikulum 2013 terutama mengenai pendekatan saintifik, saya mengajar bagaimana dengan kondisi saya sendiri.

Tujuan pembelajaran dengan pendekatan saintifik adalah sebagai berikut: (1) meningkatkan kemampuan intelektual, khususnya kemampuan berpikir tingkat tinggi peserta didik: (2) membentuk kemampuan peserta didik dalam menyelesaikan suatu masalah secara sistematik; (3) memperoleh hasil belajar yang tinggi; (4) melatih peserta didik dalam mengkomunikasikan ide-ide, khususnya dalam menulis karya ilmiah, serta (5) mengembangkan karakter peserta didik, Panduan Penguatan Proses pembelajaran Sekolah Menengah Pertama (Kemendikbud, 2013, p4). Dalam prinsip pembelajaran dengan pendekatan saintifik ditemukan kendala, yang penting guru harus memberikan arahan sebelum siswa mulai menyerap pembelajaran di kelas, prinsip yang sesuai dengan karakteristik siswa yang berbeda, sehingga saya sebagai guru perlu pelatihan secara mendalam mengenai Kurikulum 2013 yang menekankan pendekatan saintifik.

Prinsip-prinsip pembelajaran dengan pendekatan saintifik adalah sebagai berikut ( Hosnan, 2014, p 37): 1)Berpusat pada peserta didik yaitu kegiatan aktif peserta didik secara fisik dan mental dalam membangun makna atau pemahaman suatu konsep, hukum/prinsip. 2) Membentuk students' self concept yaitu membangun konsep berdasarkan pemahaman sendiri. 3) Menghindari verbalisme. 4) Memberi kesempatan pada peserta didik untuk mengasimilasi dan mengakomodasi konsep, hukum, dan prinsip. 5) Mendorong terjadinya peningkatan kecapakan berpikir peserta di- dik. 6) Meningkatkan motivasi belajar peserta didik. 7) Memberikan kesempatan kepada peserta didik untuk melatih kemampuan dalam komunikasi. 8)Memungkinkan adanya proses validasi terhadap konsep, hukum, dan prinsip yang dikonstruksi peserta didik dalam struktur kognitifnya. Langkah-langkah dalam pendekatan saintifik pada Kurikulum 2013 sangat bagus dan sistematis tapi belum semua langkah saya bisa jalankan terutama pada kegiatan hal mengamati yaitu guru terkadang sulit menentukan objek yang akan diamati oleh siswa, selain itu guru harus mempersiapkan sarana yang menunjang agar siswa dapat lebih mudah untuk mengamati tema yang disampaikan oleh guru. Ada juga kesulitannya siswa yang kurang aktif sehingga guru harus dapat memberi motivasi pada siswa. Saya setuju jika Kurikulum 2013 di kembangkan atau dilanjutkan namun saya berharap pemerintah terus memprogramkan pelatihan-pelatihan aplikatif untuk para guru sasaran terutama pada daerah remote sesuai kapasitas lembaga-lembaga terkait baik dalam bentuk diklat, diklat di tempat kerja, workshop, lokakarya dan bimbingan teknis (bimtek) secara intensif agar pemahaman guru-guru yang ada di kecamatan lebih memahami Kurikulum 2013 sehingga dalam pelaksanaanya bisa berjalan dengan tujuan dari kurikulum tersebut.

Selanjutnya pendapat empat guru IPS terhadap penilaian autentik dalam Kurikulum 2013, pertama di uraikan dua guru yang menjawab pernyataan sangat sesuai baru kemudian akan di uraikan guru yang menjawab tidak sesuai dalam pemahamannya mengenai konsep penilaian autentik, penilaian autentik dalam instrument penilaian kompetensi sikap, penilaian autentik dalam instrument penilaian kompetensi pengetahuan, dan penilaian autentik dalam instrument penilaian kompetensi keterampilan dan tanggapanya mengenai Kurikulum 2013 dilajutkan atau dihentikan. Penilaian autentik sebenarnya sangat baik untuk diterapkan namun guru harus melakukan penilaian secara sistematis agar dapat meliputi seluruh kompetensi dari siswa seperti kompetensi sikap, pengetahuan, dan keterampilan. Penilaian autentik mengajarkan kepada 
siswa tentang pembelajaran yang bermakna. Menurut Gulikers (2006, p 6) penilaian autentik merangsang siswa untuk mengembangkan keterampilan dan kompetensi yang relevan untuk dunia kerja. Penilaian autentik dapat juga digunakan untuk mengasah keterampilan siswa. Hal ini sesuai yang dituliskan oleh Mueller (2012), bahwa penilaian autentik merupakan suatu bentuk penilaian dimana siswa diminta untuk melakukan tugas-tugas dunia nyata yang menunjukkan aplikasi bermakna dari pengetahuan dan keterampilan. Dalam penilaian kompetensi sikap bahwa dapat dilakukan bersamaan dengan proses belajar siswa namun penilaiannya sangat individu bagi siswa sehingga kurang baik jika menilai pada kelompok siswa yang relatif banyak jumlahnya.

Penilaian autentik dalam penilaian kompetensi pengetahuan yaitu penilaian ini lebih mudah untuk diketahui sebab guru bisa mengetahui dari hasil belajar siswa. Dalam penilaian kompetensi keterampilan bahwa apabila penilaian dilakukan secara baik maka akan mempermudah guru menilai siswa namun hal ini membutuhkan kecermatan dalam melakukan pengamatan pada semua siswa. Sistem penilaian harus dikembangkan sejalan dengan perkembangan model dan strategi pembelajaran (Hartati Muchtar, 2010). Kemudian guru menyatakan Saya akan mengikuti kebijakan pemerintah, apapun keputusan pemerintah saya akan melaksanakannya, misalnya Kurikulum 2013 di lanjutkan atau dihentikan. Kurikulum 2013 mempertegas adanya pergeseran dalam melakukan penilaian, yakni dari penilaian melalui tes (mengukur kompetensi pengetahuan berdasarkan hasil saja), menuju penilaian autentik (mengukur kompetensi sikap, keterampilan, dan pengetahuan berdasarkan proses dan hasil). Dalam penilaian autentik peserta didik diminta untuk menerapkan konsep atau teori pada dunia nyata. Autentik berarti keadaan yang sebenarnya, yaitu kemampuan atau keterampilan yang dimiliki oleh peserta didik. Misalnya, peserta didik diberi tugas proyek untuk melihat kompetensi peserta didik dalam menerapkan pengetahuan yang dimiliki peserta didik dalam kehidupan sehari-hari atau dun- ia nyata (Kunandar, 2013, p 36).

Penilaian autentik adalah kegiatan menilai peserta didik sesuai dengan fakta yang menekankan pada apa yang seharusnya dinilai, baik proses maupun hasil dengan berbagai instrumen penilaian. Penilaian autentik dalam Kurikulum 2013 Salah satu penekanan dalam Kurikulum 2013 adalah penilaian autentik ( $a u$ thentic assessment). Selanjutnya berdasarkan hasil wawancara dengan dua guru IPS yang dalam kategori tidak sesuai pemahamannya terhadap konsep penilaian autentik, penilaian autentik dalam instrument penilaian kompetensi sikap, penilaian autentik dalam instrument penilaian kompetensi pengetahuan, dan penilaian autentik dalam instrument penilaian kompetensi keterampilan dan tanggapanya mengenai Kurikulum 2013. Menyatakan bahwa: penilaian autentik sebenarnya sudah dilakukan pada Kurikulum KTSP namun dalam implementasinya di lapangan belum berjalan secara optimal.

Mardapi (2012, p 165) outintik asisment adalah salah satu bentuk asismen salah satu bentuk asisment yang meminta peserta didik untuk menerapkan konsep atau teori pada dunia nyata. Sementara menurut (Hosnan, 2014: 388) berbagai tipe asesment otentik adalah; a) asesmen kinerja, b) observasi dan pertanyaan, c) presentasi dan diskusi, d) proyek dan investigasi, e) portofolio dan jurnal. Penilain sikap itu sudah baik hanya kadang saya sulit untuk menilai sikap, hal ini disebabkan karena siswa sangat banyak pada setiap kelas dan masih bingung dengan instrument yang digunakan karena belum pernah mendapatkan pelatihan mengenai penilaian autentik dalam Kurikulum 2013. Selanjutnya penilaian autentik dalam penilaian kompetensi pengetahuan bahwa dalam menilai siswa tidak terlalu sulit karena mudah diukur dengan memberikan tes tulis pada siswa. Sedangkan penilaian autentik dalam penilaian kompetensi keterampilan bahwa penilaian ini membutuhkan waktu yang sangat lama sehingga guru kadang sulit melakukan penilaian kepada semua sisiwa di kelas. Meskipun belum sepenuhnya memahami penilaian autentik secara meneyeluruh ter- 
utama saya masih bingung dengan penialain autentik dalam Kurikulum 2013, namun saya akan tetap menjalankan kebijakan pemerintah, apapun keputusan pemerintah saya akan tetap melaksanakannya, namun saya berharap pemerintah memperhatikan guru di pelosok untuk lebih memberikan sosilisasi, pelatihan dan penataran secara intensif agar guru-guru di kecamatan bisa memahami Kurikulum 2013 dengan baik.

\section{SIMPULAN}

Berdasarkan hasil penelitian dan pembahasan di atas dapat disimpulkan bahwa pemahaman guru mata pelajaran Ilmu Pengetahuan Sosial terhadap pendekatan saintifik dalam Kurikulum 2013 di Sekolah Menegah Pertama Negeri se Kecamatan Praya Timur Kabupaten Lombok Tengah di kategori sangat sesuai sebanyak 3 guru, kategori sesuai sebanyak 11 guru, kategori tidak sesuai sebanyak 4 guru. Menujukkan pemahaman guru terhadap pendekatan saintifik sebagian besar dipahami oleh guru. Hal ini menujukkan sebagian besar guru memahami konsep pendekatan saintifik, tujuan pendekatan saintifik, dan prinsip pendekatan saintifik, namun guru belum memahami secara sistematis pelaksanaan langkah-langkah pendekatan saintifik. Meskipun demikian guru setuju dengan implementasi Kurikulum 2013 dan beranggapan kurikulum tersebut bisa dilanjutkan atau dikembangkan dengan kapasitas pemerintah dan lembagalembaga terkait baik dalam bentuk diklat, diklat di tempat kerja, workshop, lokakarya dan bimbingan teknis (bimtek) secara intensif mensosialisasikan kurikulum baru agar pemahaman guru-guru yang ada di kecamatan lebih memahami Kurikulum 2013 sehingga dalam pelaksanaanya bisa berjalan dengan tujuan dari kurikulum tersebut, sehingga dalam proses di lapangan tidak terjadi kesalahpahaman dalam implementasinya.

Pemahaman guru mata pelajaran Ilmu Pengetahuan Sosial terhadap penilaian autentik dalam Kurikulum 2013 di Sekolah Menegah Pertama Negeri se Kecamatan Praya Timur Kabupaten Lombok Tengah, diketahui Pada kategori sangat sesuai sebanyak 2 guru, kategori sesuai sebanyak 7 guru, kategori tidak sesui sebanyak 9 guru. Menunjukkan pemahaman guru sebagian besar belum memahami penilaian autentik dalam Kurikulum 2013 dengan maksimal. Hal ini menujukkan sebagian besar guru hanya memahami konsep penilaian autentik dan instrument penilaian kompetensi pengetahuan namun guru belum memahami secara komprehensif instrument penilaian kompetensi sikap dan keterampilan. Meskipun demikian guru setuju dengan implementasi Kurikulum 2013 dan beranggapan kurikulum tersebut bisa dilanjutkan atau dikembangkan dengan kapasitas pemerintah dan lembaga-lembaga terkait baik dalam bentuk diklat, diklat di tempat kerja, workshop, lokakarya dan bimbingan teknis (bimtek) secara intensif mensosialisasikan kurikulum baru agar pemahaman guru-guru yang ada di kecamatan lebih memahami Kurikulum 2013 sehingga dalam pelaksanaanya bisa berjalan dengan tujuan dari kurikulum tersebut, sehingga dalam proses di lapangan tidak terjadi kesalahpahaman dalam implementasinya.

\section{UCAPAN TERIMA KASIH}

Kami ucapkan terima kasih kepada para informan yang terlibat dalam penelitian ini, terutama para guru mata pelajaran IPS SMP Negeri se Kecamatan Praya Timur, sehingga penelitian ini dapat berjalan dengan baik. Selain itu kami ucapkan terima kasih kepada pihak-pihak yang turut membantu support dana sehingga penelitian ini dapat berjalan dengan lancar. Terima kasih kepada redaksi yang telah mempublikasikan artikel hasil penelitian ini.

\section{DAFTAR PUSTAKA}

Christine V. McLelland 2014. The nature of science and the scientific method. GSA distinguished earth science educator in residence: Harvard Business Review Press.

Dyer, J., et al. 2011. The innovator's dna. Boston: Harvard Business Review Press.

Febri Hendri. Kritik Kurikulum 2013: Layu Sebelum Berkembang. Kompas, Jumat, 19 September 2014.) 
Gulikers. 2006. The Case of Authentic Assessment. Eric Identifier. 12 (0): 1-4

http://www.aswanblog.com/2013/04/KOMPAS/problemat ka-kurikulum-2013 tinjauan.html)

Hartati Muchtar. 2010. Meneliti tentang "Penerapan penilaian autentik dalam upaya peningkatan mutu pendidikan guru besar universitas negeri Jakarta. Jurnal Pendidikan Penabur - No.14/Tahun ke-9/Juni 2010.

Hosnan, 2014. Pendekatan saintifik dan kontekstual dalam pembelajaran abad 21, kunci sukses implmentasi kurikulum 2013. Bogor: Ghalia Indonesia.
Kunandar. 2013. Penilaian autentik, penilaian hasil belajar peserta didik berdasarkan Kurikulum 2013. Jakarta: RajaGrafindo Persada. Mueller Jon. 2012. Authentic Assessment Tool Box, (Online)

Mardapi, D. 2008. Teknik penyusunan instrumen tes dan nontes. Yogyakarta: Mitra Cendikia.

Permendikbud. 2013. Nomor 68 tentang Kerangka dasar dan struktur Kurikulum sekolah menengah pertama/madrasah tsanawiyah..

Sugiyono. 2010. Metode penelitian pendidikan pendekatan kuantitatif, kualitatif, dan r\&d. Bandung: Alfabeta. 